\title{
A Complete Overview and Guidelines for nCOv-2019 (COVID-19) with Special Reference to Corporate Hospital
}

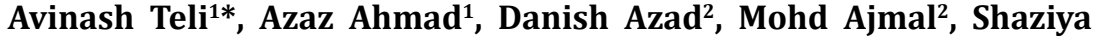 Sheikh ${ }^{3}$ and Arvind Kumar ${ }^{3}$}

${ }^{1}$ Department of Clinical Pharmacology, Nayati Medicity, Mathura, Uttar Pradesh, India

${ }^{2}$ Department of Clinical Pharmacology, Eternal Hospital, Jaipur, Rajasthan, India ${ }^{2}$ Departement of Pharmacy Practice, Integral University, Lucknow, Uttar Pradesh, India

${ }^{3}$ Outreach Department, Nayati Medicity, Mathura, Uttar Pradesh, India

${ }^{3}$ Department of Quality, Sarvodaya Hospital, Faridabad, Haryana, India

*Corresponding Author: Avinash Teli, Head of Clinical Pharmacology, Nayati

Medicity, Mathura, Uttar Pradesh, India.
Received: March 23, 2020

Published: April 17, 2020

(C) All rights are reserved by Avinash Teli., et al.

\begin{abstract}
An acute respiratory disease, caused by a novel coronavirus (SARS-CoV-2, previously known as 2019-nCoV), the coronavirus disease 2019 (COVID-19) has spread throughout China and received worldwide attention. On 30 January 2020, World Health Organization (WHO) officially declared the COVID-19 epidemic as a public health emergency of international concern. Meanwhile, several independent research groups have identified that SARS-CoV-2 belongs to $\beta$-coronavirus, with highly identical genome to bat coronavirus, pointing to bat as the natural host. These policies included large-scale quarantine, strict controls on travel and extensive monitoring of suspected cases. However, it is unknown whether these policies have had an impact on the epidemic. We sought to show how these control measures impacted the containment of the epidemic. The novel coronavirus uses the same receptor, angiotensin-converting enzyme 2 (ACE2) as that for SARS-CoV and mainly spreads through the respiratory tract. Importantly, increasingly evidence showed sustained human-to-human transmission, along with many exported cases across the globe. The clinical symptoms of COVID-19 patients include fever, cough, fatigue and a small population of patients appeared gastrointestinal infection symptoms.
\end{abstract} Keywords: COVID-19; nCOv-2019; Corona Virus; Respiratory Depression; Corporate Hospital; Guidelines; Hand Hygiene; Pandemic

\section{Case Definitions}

Suspect Case

A patient with acute respiratory illness ffever and at least one sign/symptom of respiratory disease (e.g., cough, shortness of breath)\}, AND a history of travel to or residence in a country/ area or territory reporting local transmission (See NCDC website for updated list) of COVID-19 disease during the 14 days prior to symptom onset;

OR

A patient/Health care worker with any acute respiratory illness AND having been in contact with a confirmed COVID-19 case in the last 14 days prior to onset of symptoms;

OR
A patient with severe acute respiratory infection ffever and at least one sign/symptom of respiratory disease (e.g. cough, shortness breath)\} AND requiring hospitalization AND with no other etiology that fully explains the clinical presentation;

OR

A case for whom testing for COVID-19 is inconclusive.

\section{Laboratory confirmed case}

A person with laboratory confirmation of COVID-19 infection, irrespective of clinical signs and symptoms.

Definition of contact

A contact is a person that is involved in any of the following: 
- Providing direct care without proper personal protective equipments (PPE) for COVID-19 patients.

- $\quad$ Staying in the same close environment of a COVID-19 patient (including workplace, classroom, household, gatherings.

- Traveling together in close proximity (within 1 metre) with a symptomatic person who later tested positive for COVID-19.

High risk (HR) contact

1. Contact with a confirmed case of COVID-19.

2. Travelers who visited a hospital where COVID-19 cases are being treated.

3. Travel to an area where COVID-19 LOCAL TRANSMISSION is being reported as per WHO daily situation report.

4. Touched body fluids of patients (respiratory tract secretions, blood, vomitus, saliva, urine, faeces).

5. Had direct physical contact with the body of the patient including physical examination without PPE.

6. Touched or cleaned the linens, clothes or dishes of the patient.

7. Close contact, within 3 feet (1metre) of the confirmed case.

8. Co-passengers in an airplane/vehicle seated in the same row, 3 rows in front and behind of a confirmed COVID-19 case.

\section{Clinical categorization}

- Category-A: Low grade fever/mild sore throat/cough/rhinitis/diarrhoea.

- Category-B: High grade fever and/or severe sore throat/ cough.

- OR

- Category-A plus one or more of the following:

- Lung/ heart/ liver/ kidney/ neurological disease/ blood disorders/ uncontrolled diabetes/ cancer/ HIV-AIDS

- On long term steroids

- Pregnant lady

- $\quad$ Age more than 60 years.

- Category-C:

- Breathlessness, chest pain, drowsiness, fall in blood pressure, hemoptysis, cyanosis [red flag signs]

- Children with ILI (influenza like illness) with red flag signs (Somnolence, high/persistent fever, inability to feed well, convulsions, dyspnea/respiratory distress etc.).

- Worsening of underlying chronic conditions.

${ }^{*}$ Categorization should be reassessed every 28 - 48 hours for Category A and B.
Testing guidelines

- Category- A: No testing needed.

- $\quad$ Category- B and C: Testing required.

Management guidelines

Category-A

Patients should remain in strict home isolation. Doctor from Covid-19 center will telephonically monitor progress of patient and asses development of red flag signs.

\section{Patients are advised to take:}

- Plenty of warm nourishing oral fluids

- $\quad$ Balanced diet

- Adequate sleep and rest

- $\quad$ Saline gargle for sore throat if present.

Category B and C

Patient will be admitted in designated COVID-19 Floor:

- $\quad$ All suspected case of SARI will be triaged in Emergency beds dedicated for triaging.

- Infection control practices like hand hygiene, standard precautions and isolation practices to be taken as appropriate [1].

- $\quad$ Top Management and infection control nurse to be immediately notified, which in turn will convene outbreak committee meeting for further guidance.

- District health administration to be notified, if the patient falls under suspected case of nCoV 2019 as per WHO guidelines.

- $\quad$ Patient to be transferred to isolation area in $4^{\text {th }}$ Floor (Critical patient and Non Critical Patients).

- During the transport infection control practices to be followed.

- Droplet and airborne isolation to be strictly followed by all involved healthcare worker.

- Expose environment to be terminally cleaned as per Hospital infection control practices.

- Clinical Management as per National guidelines (Guidelines on Clinical management of severe acute respiratory illness (SARI) in suspect/confirmed novel coronavirus (nCoV) cases) [2].

- Healthcare workers likely to be exposed to such cases are to be trained by infection control team for hand hygiene practices, donning and doffing of PPE, standard precautions and isolation practices.

- Out-break committee has been formed comprising of following members:

- $\quad$ HOD - Critical Care

- $\quad$ HOD - Emergency 
- HOD - Internal Medicine

- $\quad$ HOD- Quality

- Medical Superintendent

- $\quad$ Chairman of IC

- Microbiologist

- Infection Control Nurse

- $\quad$ Head - Nursing

- $\quad$ Head - Supply chain management

- Head - Security

- Head - Housekeeping

- Coordinator

- Dedicated staff for screening at OPD and emergency should be trained.

- Daily reporting of such suspected cases to be done by MRD to the government authority (IDSP).

- $\quad$ Resource availability are to be ensured.

\begin{tabular}{|c|}
\hline Items \\
\hline N-95 \\
\hline Protective gowns \\
\hline Gloves \\
\hline Face Masks \\
\hline Head Caps \\
\hline Hand sanitizer \\
\hline
\end{tabular}

Table 1

\section{Clinical management}

Guideline of clinical management of severe acute respiratory illness (SARI).

\section{Guidelines for screening centres}

All hospitals would have a separate screening area to screen outdoor patients and an isolation facility to admit those requiring indoor treatment.

For clarity, these guidelines are in six parts:

1. Generic Guidelines

2. Guidelines for pre hospital care

3. Guidelines for the screening centre

4. Guidelines for isolation facility

5. Guidelines for critical care

6. Mortuary care.

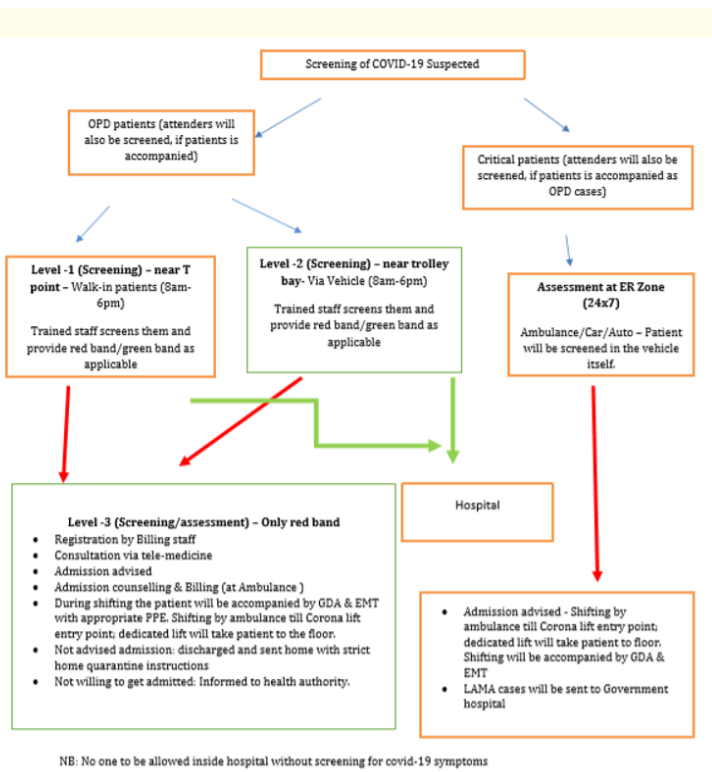

Figure 1
Generic guidelines

- Standard Precautions to be followed at all patient care areas: hand hygiene, gloves and use of personal protective equipment (PPE) to avoid direct contact with patient's blood, body fluids, secretions and non-intact skin, prevention of needle stick/sharp injury and cleaning and disinfection of the environment and equipment.

- Droplet precautions to be followed when caring for patients with 2019 nCoV-Acute Respiratory Disease (masks, respirators and eye shield) in isolation facilities.

- Airborne and Contact Precautions should complement Standard Precautions while managing case of 2019 nCoV-Acute Respiratory Disease in critical care facilities.

- Hospitals should follow the hospital waste management protocols as per the hospital waste management rules.

- $\quad$ Dead body should be handled using full cover of PPE.

Guidelines for pre hospital care

- All identified hospitals to have advanced life support ambulance.

- Designated paramedic and driver for the ambulance.

Checklist of items for preparedness of hospital labs for sample collection from suspected new corona virus outbreak cases

It is recommended that sample collection from suspected new corona virus outbreak cases should be carried out in a dedicated isolated room with independent air handling facility through use of exhaust fans and appropriate HEPA filters. 
1. Guidelines for sample collection and transportation.

2. Hand sanitizer.

3. Round the clock running water and soap.

4. PPE (Personal Protective Equipment) KITS containing at least:
a. Head cover
b. N-95 Respirator or equivalent
c. Eye goggles/Face shield
d. Full sleeved outer impermeable gown/Cover all
e. Gloves
f. Shoe Covers.

5. Patient proforma for 2019-nCoV testing.

6. VTM vials.

7. Sterile individually packed swabs with flocked nylon/Dacron/ polyester tips with synthetic shaft with break point.

8. Permanent markers.

9. Tongue depressors.

10. Triple layer packaging materials including:

a. Paraffin tape or equivalent for sealing individual VTM vials

b. Cotton or absorbent material

c. Clear zip lock bags

d. Ice packs
e. Vaccine carriers
f. Thermocol boxes
g. Biohazard labels

11. Refrigerators.

12. Deep freezers, if samples are to be stored beyond $48 \mathrm{hrs}$.

13. Facilities for disposal of bio-medical waste as per latest bio medical waste management rules:
a. Colored bins with colored disposal bio-medical waste bags, available at the anteroom for bio medical hazard
b. Puncture proof container
c. Sodium hypochlorite.

\section{SPILL KIT containing at least:}
a. PPE KIT
b. Warning labels - Biohazard, “DO NOT ENTER” sign
c. Marker/Chalk
d. $1 \%$ freshly prepared sodium hypochlorite
e. Cotton/Tissue paper rolls/Blotting paper/Absorbent mate- rial
f. Tongs /Forceps and Dust pan
g. BMW Bags
h. Mops and floor disinfectant.

Specimen collection, storage and transport details

\begin{tabular}{|l|c|c|c|c|}
\hline \multicolumn{1}{|c|}{ Specimen type } & $\begin{array}{c}\text { Collection } \\
\text { materials }\end{array}$ & $\begin{array}{c}\text { Transport to labora- } \\
\text { tory in } \mathbf{4 8}-\mathbf{7 2} \text { hrs }\end{array}$ & $\begin{array}{c}\text { Storage till } \\
\text { testing }\end{array}$ & \multicolumn{1}{|c|}{ Sample send } \\
\hline $\begin{array}{l}\text { Nasopharyngeal and oropharyngeal swab } \\
\text { (Both swabs should be placed in the same } \\
\text { tube to increase the viral load) }\end{array}$ & $\begin{array}{c}\text { Dacron or polyester } \\
\text { flocked swabs* }\end{array}$ & $4^{\circ} \mathrm{C}$ & $\begin{array}{c}\leq 72 \mathrm{hrs:} 4^{\circ} \mathrm{C} \\
>72 \mathrm{hrs:}-70^{\circ} \mathrm{C}\end{array}$ & $\begin{array}{c}\text { Outside Lab through } \\
\text { Govt. official }\end{array}$ \\
\hline Bronchoalveolar lavage & Sterile container* & $4^{\circ} \mathrm{C}$ & $\begin{array}{c}\leq 48 \text { hours: } 4^{\circ} \mathrm{C} \\
>48 \text { hours: }-70^{\circ} \mathrm{C}\end{array}$ & $\begin{array}{c}\text { Outside Lab through } \\
\text { Govt. official }\end{array}$ \\
\hline $\begin{array}{l}\text { Tracheal aspirate, nasopharyngeal aspi- } \\
\text { rate or nasal wash }\end{array}$ & Sterile container* & $4^{\circ} \mathrm{C}$ & $\begin{array}{c}\leq 48 \text { hours: } 4^{\circ} \mathrm{C} \\
>48 \text { hours: }-70^{\circ} \mathrm{C}\end{array}$ & $\begin{array}{c}\text { Outside Lab through } \\
\text { Govt. official }\end{array}$ \\
\hline $\begin{array}{l}\text { Sputum (Ensure the material is from the } \\
\text { lower respiratory tract) }\end{array}$ & Sterile container & $4^{\circ} \mathrm{C}$ & $\begin{array}{c}\leq 48 \text { hours: } 4^{\circ} \mathrm{C} \\
>48 \text { hours: }-70^{\circ} \mathrm{C}\end{array}$ & $\begin{array}{r}\text { Outside Lab through } \\
\text { Govt. official }\end{array}$ \\
\hline
\end{tabular}

\section{Table 2}

\section{Specimen packaging and transport}

Sample should be safely packed in Triple container packing and should be transported under cold chain to the reference laboratory with prior intimation. The packaging consists of three layers as follows:
1. Primary receptacle: A labelled primary watertight, leakproof receptacle containing the specimen. The receptacle is wrapped in enough absorbent material to absorb all fluid in case of breakage. 
2. Secondary receptacle: A second durable, watertight, leak-proof receptacle to enclose and protect the primary receptacle(s). Several wrapped primary receptacles may be placed in one secondary receptacle. Sufficient additional absorbent material must be used to cushion multiple primary receptacles.

3. Outer shipping package. The secondary receptacle is placed in an outer shipping package with Icepacks which protects it and its contents from outside influences such as physical damage and water while in transit.

4. Specimen data forms, letters and other types of information that identify or describe the specimen for "Testing of 2019 nCoV".

5. Samples for other routine testing that are done in-house should be sent to lab with an additional zip lock plastic cover.

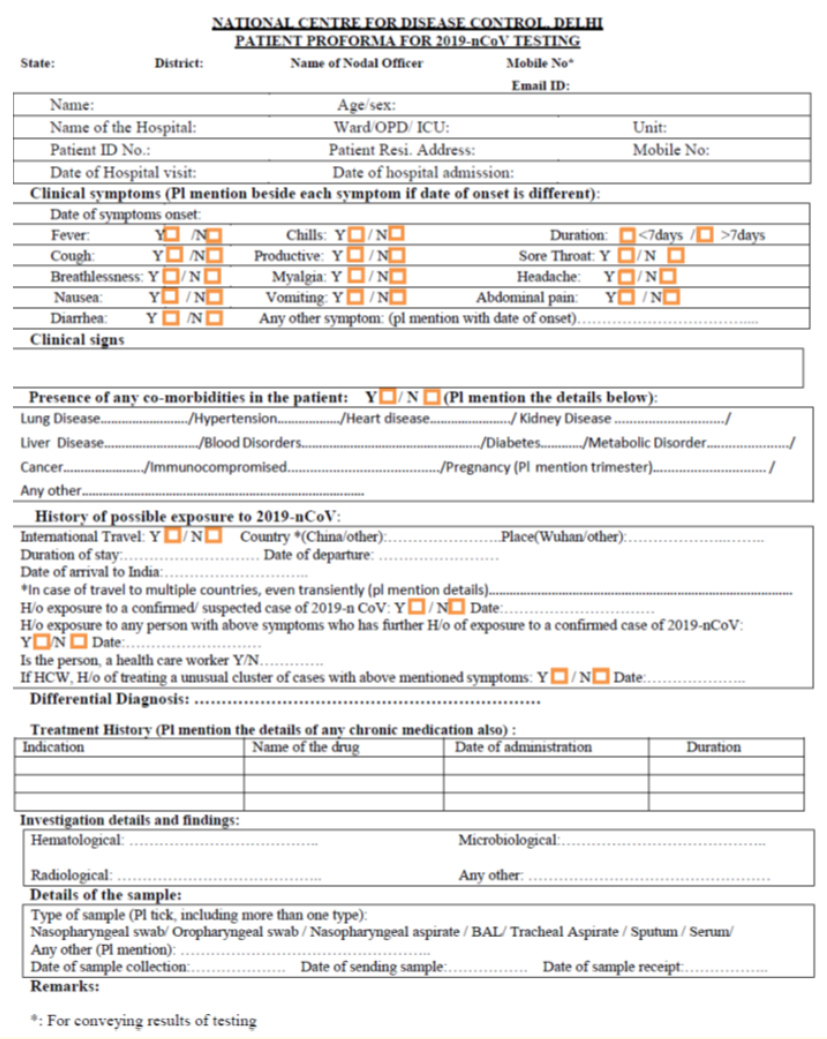

Figure 2

Infection prevention guidelines

IPC strategies to prevent or limit infection transmission in health-care settings include the following:

1. Standard Precautions

a. Hand hygiene b. Respiratory hygiene

c. Personal protective equipment (PPE).

2. Additional Precautions.

3. Bio Medical waste management.

4. Laundry management.

5. Sample collection, storage and transportation.

6. Monitor health of HCWs providing care to cases of 2019-nCoV Acute Respiratory Disease.

7. Hospital Disinfection (Environmental).

Hand-hygiene

\section{Your 5 moments for} HAND HYGIENE
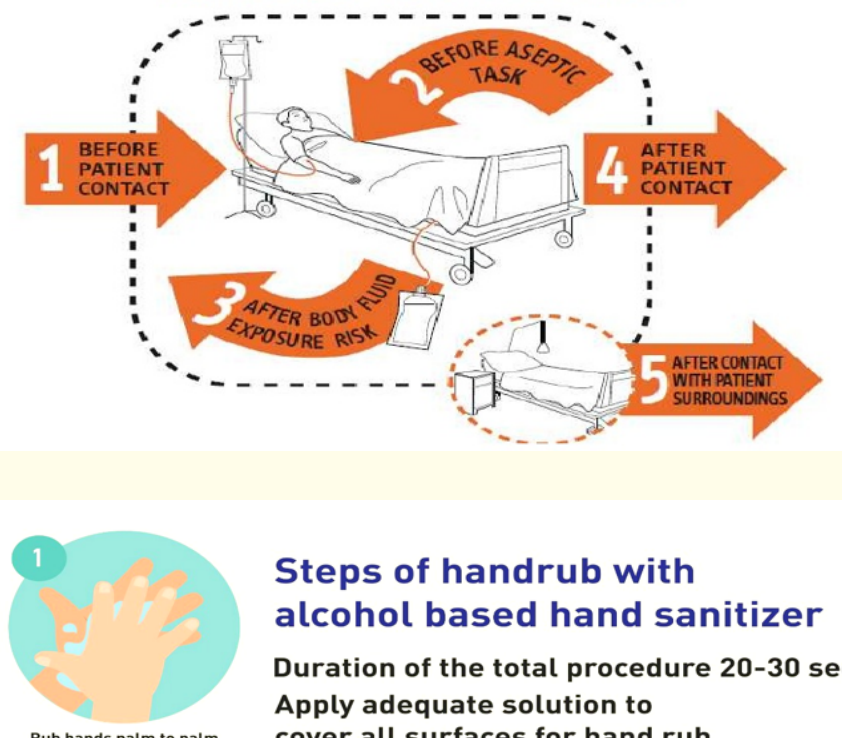

Steps of handrub with alcohol based hand sanitizer

Duration of the total procedure 20-30 sec Apply adequate solution to cover all surfaces for hand rub
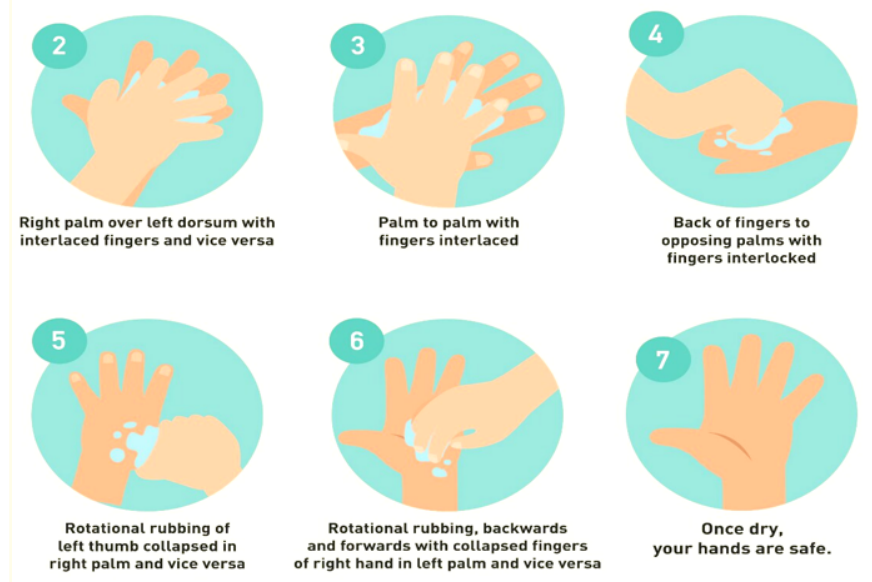


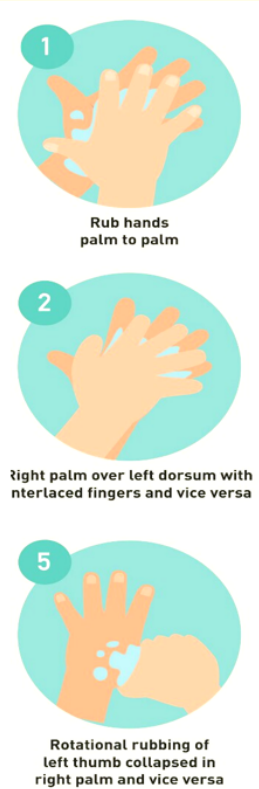

\section{Duration of the total procedure 40-60 sec}

Apply adequate soap to cover all surfaces for hand wash

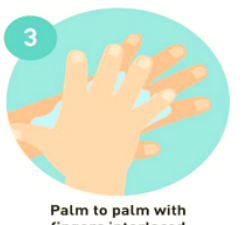

Palm to palm with
fingers interlaced
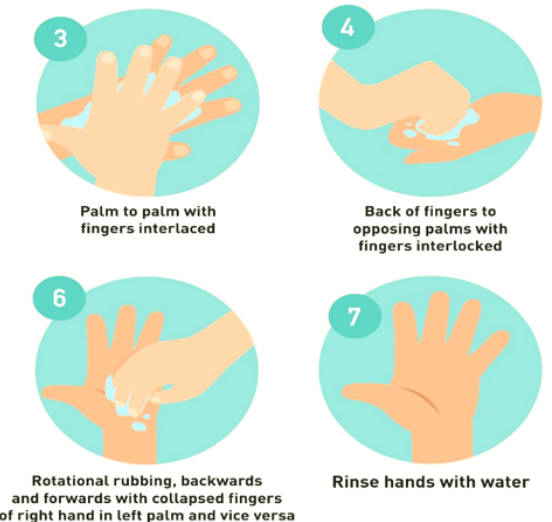

Figure 3

Respiratory hygiene

- Offer a medical/surgical mask for suspected 2019-nCoV acute respiratory disease case for those who can tolerate it.

- $\quad$ Cover nose and mouth during coughing or sneezing with tissue or flexed elbow for others.

- $\quad$ Perform hand hygiene after contact with respiratory secretions.

Personal protective equipment (PPE)

- $\quad$ PPE (special prepared PPE) includes shoe cover, gown, mask, eye protection and gloves.

- If gowns are not fluid resistant, use a waterproof apron for procedures with expected high fluid volumes that might penetrate the gown.

Donning and Doffing procedures should be diligently and carefully followed as given below

Figure 4

\section{Additional precautions}

- Cohort HCWs to exclusively care for cases to reduce the risk of spreading transmission.

- $\quad$ Place patient beds at least 1 metre apart.

- Perform procedures in an adequately ventilated room; i.e. at least natural ventilation with at least $160 \mathrm{l} / \mathrm{s} /$ patient air flow.

- Limit the number of persons present in the room to the absolute minimum required for the patient's care and support.
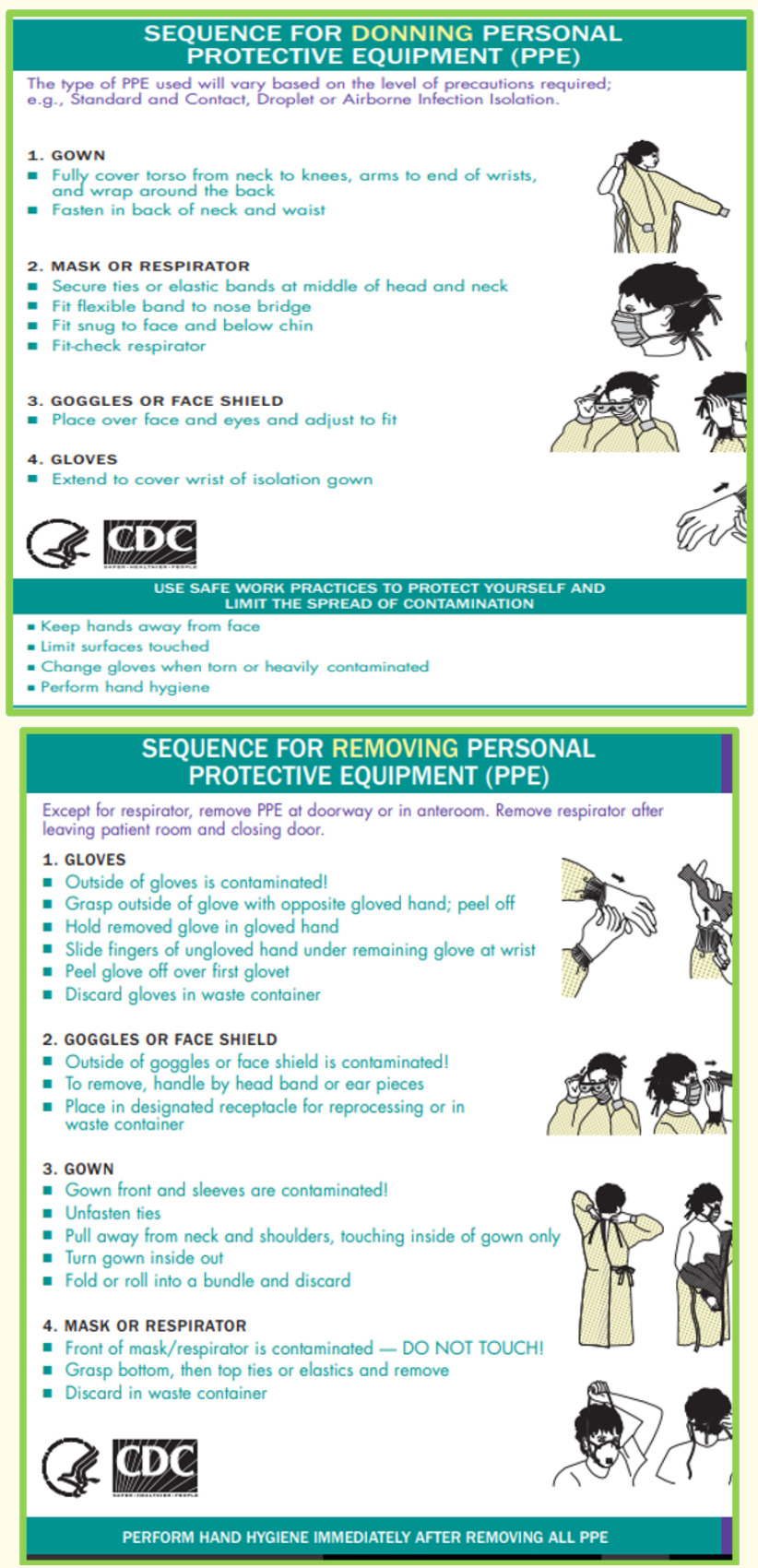

Figure 4

- Use either single use disposable equipment or dedicated equipment (e.g. stethoscopes, blood pressure cuffs and thermometers). If equipment needs to be shared among patients, clean and disinfect between each patient use (e.g. ethyl alcohol $70 \%)$.

- $\quad$ Refrain from touching eyes, nose or mouth with potentially contaminated hands. 
- Some aerosol generating procedures have been associated with increased risk of transmission of coronaviruses such as tracheal intubation, non-invasive ventilation, tracheostomy, cardiopulmonary resuscitation, manual ventilation before intubation and bronchoscopy. Ensure that HCWs performing aerosol- generating procedures use PPE with particulate respirator at least as protective as N95.

- Avoid the movement and transport of patients out of the room or area unless medically necessary.

- Use designated portable X-ray equipment and/or other important diagnostic equipment.

- If transport is required, use pre-determined transport routes to minimize exposures to staff, other patients and visitors and apply medical mask to patient.

- Ensure that HCWs who are transporting patients wear appropriate PPE as described in this section and perform hand hygiene.

- Notify the receiving area of necessary precautions as soon as possible before the patient's arrival.

- Routinely clean and disinfect patient-contact surfaces.

- Maintain a record of all persons entering the patient's room including all staff and visitors.

Laundry

- All soiled clothing bedding and linen should be gathered without creating much motion/fluffing.

- Do not shake sheets when removing them from the bed.

- Always perform hand hygiene after handling soiled laundry items.

- Laundry should be disinfected in freshly prepared $1 \%$ Sodium hypochlorite and then transported to laundry in tightly sealed and labelled Yellow bag.

Disinfection (Environmental)

- Environmental surfaces or objects contaminated with blood, other body fluids, secretions or excretions should be cleaned and disinfected using standard hospital detergents/disinfectants Approved by CDC and US-EPA e.g. freshly prepared $1 \%$ Sodium Hypochlorite or $1 \%$ Mi fog.

- The contact period of the chemical with the surface should be min. of 30 minutes.

- Disinfect all external surfaces of specimen containers thoroughly (using an effective disinfectant) prior to transport. E.g.
Sodium hypochlorite at $1 \%, 500 \mathrm{ppm}$ available chlorine (i.e. 1:100 dilution of household bleach at initial concentration of $5 \%$ ) or $5 \%$ Lys.

- Do not spray (i.e. fog) occupied or unoccupied clinical areas with disinfectant. This is a potentially dangerous practice that has no proven disease control benefit.

- Wear gloves, gown, mask and closed shoes (e.g. boots) when cleaning the environment and handling infectious waste. Cleaning heavily soiled surfaces (e.g. soiled with vomit or blood) increases the risk of splashes. On these occasions, facial protection should be worn in addition to gloves, gown and closed, resistant shoes. Wear gloves, gown, closed shoes and goggles/facial protection, when handling liquid infectious waste (e.g. any secretion or excretion with visible blood even if it originated from a normally sterile body cavity). Avoid splashing when disposing of liquid infectious waste.

- Clean and disinfect mattress impermeable covers.

- Non-critical instruments /equipment (that are those in contact with intact skin and no contact with mucous membrane) require only intermediate or low level disinfection before and after use.

- COVID-19 OPD: in-between patient consultation, clean the equipment's, floor and environment with $1 \%$ sodium hypochlorite solution/1\% MiFog.

- Use couch sheet/tissue paper before applying BP cuff and discard after each use.

Bio Medical Waste Management from suspected case of nCoV-

19

- $\quad$ All articles like swab, syringes, IV set, PPE etc are to be discarded in yellow bag.

- All sharps like needle etc are to be collected in puncture proof container which should be discarded in yellow bag.

Color-coded bags and colour category wise treatment (Table 4)

Ambulance transfer

When a suspect case of 2019 nCoV-Acute Respiratory Disease patient has to be transported, the following precautions should be taken by ambulance personnel accompanying the patient.

On arrival to the healthcare facility from where the patient is to be transferred:

1. Decontaminate hands (alcohol rub) (Fig).

2. Done Personal Protective Equipment (PPE). 


\begin{tabular}{|c|c|c|c|}
\hline Area/Items & Item/Equipment & Process & Method/ Procedure \\
\hline \multicolumn{4}{|c|}{ Clinical Area } \\
\hline $\begin{array}{l}\text { Floors (clinical } \\
\text { areas) - daily } \\
\text { mopping }\end{array}$ & $\begin{array}{l}\text { Detergent/sanitizer-hot } \\
\text { water, 1\% Mifog } \\
\text { Three buckets (one with } \\
\text { plain water and one with } \\
\text { detergent solution; one } \\
\text { bucket for Mifog (1\%) }\end{array}$ & $\begin{array}{c}\text { Sweeping } \\
\text { Cleaning } \\
\text { Daily mopping }\end{array}$ & $\begin{array}{l}\text { - Sweep with the dust mop or damp mop to remove surface dust. } \\
\text { - Tweep under the furniture and remove dust from corners. Gath- } \\
\text { ered dust must be removed using a hearth brush and shovel. } \\
\text { - } \quad \text { Prepare cleaning solution using detergent with warm water } \\
\text { - } \text { Use the three-bucket technique for mopping the floor, one } \\
\text { bucket with plain water and one with the detergent solution. } \\
\text { - } \quad \text { First mop the area with the warm water and detergent solution. } \\
\text { - } \text { Repeat this procedure for the remaining area. } \\
\text { - } \text { Mop area again using Mifog (1\%) after drying the area. } \\
\text { - } \text { quently. } \\
\text { Mop the floor starting at the far corner of the room and work } \\
\text { - Clean articles between cleaning. } \\
\text { Note: Mopping should be done thrice a day }\end{array}$ \\
\hline \multirow[t]{2}{*}{$\begin{array}{l}\text { Ceiling and } \\
\text { Walls }\end{array}$} & $\begin{array}{l}\text { Sweeping tool } \\
\text { Duster } \\
\text { Bowl/small bucket of soap } \\
\text { solution } \\
\text { Plain water }\end{array}$ & Damp dusting & $\begin{array}{l}\text { - Damp dusting with a long handled tool for the walls and ceiling } \\
\text { done with very little moisture, just enough to collect the dust. } \\
\text { Damp dusting should be done in straight lines that overlap one } \\
\text { another. } \\
\text { - Change the mop head/cover when soiled. } \\
\text { Note: Should be done once a week or after examining a suspect case }\end{array}$ \\
\hline & Care of mop & $\begin{array}{c}\text { Hot water Detergent } \\
\text { Mifog }(1 \%)\end{array}$ & $\begin{array}{l}\text { - Clean with hot water and detergent solution, disinfect it with Mi- } \\
\text { fog }(1 \%) \text { and keep for drying upside down. }\end{array}$ \\
\hline $\begin{array}{l}\text { Doors and door } \\
\text { knobs }\end{array}$ & $\begin{array}{l}\text { Damp cloth or Sponge } \\
\text { squeeze mop Detergent }\end{array}$ & \begin{tabular}{|l|} 
Thorough washing \\
\end{tabular} & $\begin{array}{l}\text { - The doors are to be washed with a brush, using detergent and } \\
\text { water once a week (on one defined day); gently apply cloth to } \\
\text { soiled area, taking care not to remove paint, then wipe with } \\
\text { warm water to remove excess cleaning agent. } \\
\text { Door knobs and other frequently touched surfaces should be } \\
\text { cleaned daily. }\end{array}$ \\
\hline Isolation room & $\begin{array}{l}\text { Detergent/Sanitizer- warm } \\
\text { water, Mifog (1\%) Three } \\
\text { buckets (one with plain wa- } \\
\text { ter and one with detergent } \\
\text { solution); separate bucket } \\
\quad \text { for Mifog (1\%) }\end{array}$ & Terminal cleaning & $\begin{array}{l}\text { - Before cleaning an isolation room, liaise with infection control } \\
\text { team for details of any special requirements. Staff will be in- } \\
\text { structed on specific cleaning procedures required with refer- } \\
\text { ence to Safety uniform to be worn, Chemicals or disinfectants } \\
\text { to be used. } \\
\text { Also, if bed screen and shower screen are to be cleaned or } \\
\text { changed, refer cleaning in isolation rooms. }\end{array}$ \\
\hline $\begin{array}{l}\text { All clinical } \\
\text { areas/ } \\
\text { Laboratories/ } \\
\text { Wherever } \\
\text { spill care is } \\
\text { required }\end{array}$ & $\begin{array}{c}\text { Mifog (1\%), } \\
\text { Absorbent paper } \\
\text { Unsterile gloves } \\
\text { Spill care kit } \\
\text { Mop } \\
\text { Hot water }\end{array}$ & $\begin{array}{l}\text { Blood and body } \\
\text { fluid spill care }\end{array}$ & $\begin{array}{l}\text { - Wear non-sterile gloves. } \\
\text { - For large spills, cover with absorbent paper/ rag piece if any } \\
\text { broken glass and sharps, using a pair of forceps and gloves, } \\
\text { carefully retrieve. Use a large amount of folded absorbent pa- } \\
\text { per to collect small glass splinters. Place the broken items into } \\
\text { the puncture proof sharps container. } \\
\text { - Cover the spill with Mifog (1\%) for 10-20 minutes contact } \\
\text { time. } \\
\text { - Clean up spill and discard into infectious waste bin, and mop } \\
\text { area with soap and hot water. } \\
\text { - Clean the mop and mop area with Mifog (1\%) } \\
\text { Wash mop with detergent and hot water and allow it to dry. }\end{array}$ \\
\hline
\end{tabular}




\begin{tabular}{|c|c|c|c|}
\hline Stethoscope & $\begin{array}{l}\text { Alcohol-based rub/Spirit } \\
\text { swab }\end{array}$ & Cleaning & $\begin{array}{l}\text { - Should be cleaned with detergent and water. } \\
\text { - Should be wiped with alcohol based rub/spirit swab before } \\
\text { each patient contact. }\end{array}$ \\
\hline $\begin{array}{l}\text { BP cuffs and } \\
\text { covers }\end{array}$ & $\begin{array}{l}\text { Detergent } \\
\text { Hot water }\end{array}$ & Washing & $\begin{array}{l}\text { - Cuffs should be wiped with alcohol- based disinfectant and } \\
\text { regular laundering is recommended for the cover. }\end{array}$ \\
\hline Thermometer & $\begin{array}{l}\text { Alcohol rub Individual } \\
\text { thermometer holder }\end{array}$ & Cleaning & $\begin{array}{l}\text { - } \quad \text { Should be stored dry in individual holder. } \\
\text { - } \quad \text { Clean with detergent and tepid water and wipe with alcohol } \\
\text { rub in between patient use. } \\
\text { - } \quad \text { Store in individual holder inverted. } \\
\text { - } \quad \text { Preferably one thermometer for each patient. }\end{array}$ \\
\hline $\begin{array}{l}\text { Injection tray } \\
\text { and dressing } \\
\text { trolley }\end{array}$ & $\begin{array}{l}\text { Detergent and water } \\
\text { Duster Disinfectant (70\% } \\
\text { alcohol) }\end{array}$ & Cleaning & $\begin{array}{l}\text { - To be cleaned daily with detergent and water. } \\
\text { - } \quad \text { After each use should be wiped with disinfectant. }\end{array}$ \\
\hline Refrigerators & $\begin{array}{l}\text { Detergent and water } \\
\text { Absorbent paper or clean } \\
\text { cloth }\end{array}$ & Cleaning (weekly) & $\begin{array}{l}\text { - } \\
\text { - } \\
\text { - } \\
\text { - } \\
\text { - } \\
\text { Defy it prost, decontaminate and clean with detergent. } \\
\text { Weekly cleaning is recommended. }\end{array}$ \\
\hline
\end{tabular}

Table 3

\begin{tabular}{|c|c|c|c|}
\hline Category & Type of Waste & $\begin{array}{c}\text { Type of Bag or Container to } \\
\text { be used* }\end{array}$ & Treatment and Disposal options \\
\hline$(1)$ & $(2)$ & $(3)$ & $(4)$ \\
\hline \multirow[t]{3}{*}{ Yellow } & (a) Human Anatomical Waste: & \multirow{2}{*}{$\begin{array}{l}\text { Yellow coloured non- chlori- } \\
\text { nated plastic bags }\end{array}$} & \multirow{2}{*}{ Incineration by CBMWTF } \\
\hline & (b) Animal Anatomical Waste: & & \\
\hline & $\begin{array}{l}\text { (c) Soiled Waste: Items contaminated } \\
\text { with blood, body fluids like dressings, } \\
\text { plaster casts, cotton swabs }\end{array}$ & & Incineration by CBMWTF \\
\hline & $\begin{array}{l}\text { (d) Expired or Discarded Medicines: } \\
\text { antibiotics, cytotoxic drugs }\end{array}$ & $\begin{array}{l}\text { Yellow coloured non- chlori- } \\
\text { nated plastic bags or contain- } \\
\text { ers with cytotoxic labels }\end{array}$ & $\begin{array}{l}\text { Expired cytotoxic drugs to be returned back to } \\
\text { the manufacturer or supplier. } \\
\text { for incineration at temperature }>1200^{\circ} \mathrm{C} \text {. } \\
\text { Leftover cytotoxic drugs and items contami- } \\
\text { nated with cytotoxic drugs along with glass or } \\
\text { plastic ampoules, vials etc to common biomedi- } \\
\text { cal waste treatment facility for incineration at } \\
>>1200^{\circ} \mathrm{C} \text {. }\end{array}$ \\
\hline & $\begin{array}{l}\text { (e) Chemical Waste: solid discarded } \\
\text { chemicals }\end{array}$ & $\begin{array}{c}\text { Yellow coloured non- chlori- } \\
\text { nated plastic bags or contain- } \\
\text { ers }\end{array}$ & Disposed of by incineration by CBMWTF \\
\hline & $\begin{array}{l}\text { (f) Chemical Liquid Waste: Liquid Waste } \\
\text { generated due to use of chemicals and } \\
\text { used or discarded disinfectants. }\end{array}$ & $\begin{array}{l}\text { Separate collection system } \\
\text { leading to effluent treatment } \\
\text { plant (ETP) system. }\end{array}$ & $\begin{array}{c}\text { After resource recovery, the chemical liquid } \\
\text { waste shall be pre-treated before mixing with } \\
\text { other wastewater. The combined discharge } \\
\text { shall conform to the discharge norms given in } \\
\text { BMWM rules, } 2016\end{array}$ \\
\hline & $\begin{array}{l}\text { (g) Discarded linen: contaminated with } \\
\text { blood or body fluid. }\end{array}$ & $\begin{array}{l}\text { Non-chlorinated yellow plas- } \\
\text { tic bags or suitable }\end{array}$ & $\begin{array}{l}\text { Non-chlorinated (alcoholic: 5\%lysol, } 5 \% \\
\text { phenol) chemical disinfection followed by } \\
\text { incineration. }\end{array}$ \\
\hline & Routine mask and gown & Packing material & \\
\hline & $\begin{array}{l}\text { (h) Microbiology, Biotechnology and } \\
\text { other clinical laboratory waste, PVC } \\
\text { Blood bags }\end{array}$ & $\begin{array}{l}\text { Autoclave safe plastic bags or } \\
\text { containers }\end{array}$ & $\begin{array}{l}\text { Autoclave or Pre-treat to disinfect. Treated } \\
\text { waste to be sent to CBMWTF for incineration. }\end{array}$ \\
\hline
\end{tabular}




\begin{tabular}{|c|c|c|c|}
\hline Red & $\begin{array}{c}\text { Contaminated Waste (Recyclable) } \\
\text { Plastics tubing, bottles, intravenous } \\
\text { tubes and sets, catheters, urine bags, } \\
\text { syringes (without needles and fixed } \\
\text { needle syringes) and vacutainers with } \\
\text { their needles cut) and gloves }\end{array}$ & $\begin{array}{c}\text { Red coloured non chlorinated } \\
\text { plastic bags or containers }\end{array}$ & $\begin{array}{c}\text { Autoclaving/Chemical disinfection. Treated } \\
\text { waste to be sent to CBMWTF who would send } \\
\text { such waste to registered or authorized recy- } \\
\text { clers or for energy recovery }\end{array}$ \\
\hline $\begin{array}{c}\text { White } \\
\text { Translu- } \\
\text { cent) }\end{array}$ & Waste sharps & Puncture proof, Leak proof, \\
Blue & $\begin{array}{c}\text { Tamper proof containers } \\
\text { Glass: medicine glass vials or broken or } \\
\text { discarded and contaminated glass }\end{array}$ & $\begin{array}{c}\text { Disinfection/Autoclaving or dry heat steriliza- } \\
\text { tion/ sent to CBMWTF and who will ensure } \\
\text { final disposal to iron foundries (having consent } \\
\text { to operate from the SPCB/PCC. }\end{array}$ \\
\hline with blue coloured marking \\
\end{tabular}

Table 4

A patient requiring Aerosol Generating Precaution: N95 mask, gloves, long sleeved fluid repellent gown and goggles (Annexure donning PPE).

3. Inform the hospital of the admission/transfer of a potentially infectious person.

Before leaving the house/healthcare facility

- Request patient to wear a surgical mask and advise on Respiratory Hygiene and Cough Etiquette.

- A patient with suspected or confirmed 2019nCoV-Acute Respiratory Disease should not travel with other patients.

In ambulance

- Remove gloves, decontaminate hands and put on new gloves before touching the patient and before a clean or aseptic procedure, if required. Wearing gloves does not replace hand hygiene.

- Use single use or single patient use medical equipment where possible.

- Use disposable linen if available.

Arrival to the referral hospital

- Before the patient leaves the ambulance ensure arrangements are in place for receipt of the patient.

- Transfer patient to the care of hospital staff.

- $\quad$ After transfer of patient remove PPE.

- Perform hand hygiene.

Before ambulance is used again

- Cleaning and disinfecting: (PPE as outlined above should be worn while cleaning), Surfaces (stretcher, chair, door handles etc) should be cleaned with a freshly prepared $1 \%$ hypochlorite solution or $1 \%$ Mifog.

- Laundry: Place reusable blankets in a bag, then put into a laundry bag and send for laundering clearly labelling it so that person in the laundry wears appropriate PPE before handling or autoclaves it before opening.

- Medical equipment: Follow manufacturer's instructions for cleaning/disinfecting reusable equipment (see guidelines).

- Management of waste: All masks and any waste contaminated with blood or body fluid (including respiratory secretions) should be disposed of as infectious waste in yellow bag.

- Management of sharps: Per Standard Precautions.

- Management of spillages of blood and body fluids: Per Standard Precautions.

In the ambulance, if the driver's chamber is not separate, driver should also use PPE.

Guidelines for Home based care of 2019-nCoV

Any person(s) suggestive of 2019-nCoV, should be confined at home for a period of 14 days and avoid close contact with public and other members in the family.

Guiding principles for home care

1. Be informed about the illness.

2. Stay home, preferably isolate himself/herself in a separate and well-ventilated room. Avoid common areas frequented by other members of the family. 
3. Avoid close contact with others. If inevitable, always maintain at-least two meters distance.

4. Avoid having visitors.

5. Avoid frequent touching of face.

6. Avoid handshaking and wash hands frequently with soap and water. In case of non-availability of soap and water, commercially available hand rubs can be used.

7. Take plenty of fluids.

8. Follow cough etiquettes:

a. Cover mouth and nose with a tissue/ handkerchief when coughing or sneezing; In case tissue/ handkerchief is not available cough/ sneeze onto your upper arm or shoulder; coughing/sneezing directly on to hands should not be done.

b. Turn away from others when coughing or sneezing.

c. Do not spit/ blow nose here and there, use a water filled receptacle for collecting sputum, thereby minimizing aerosol generation.

Monitor your health for appearance of symptoms like fever, cough and/or breathing difficulty. If you develop any of these symptoms Please do contact the nearest Government Health Facility.
For any further information Please contact District Surveillance Office.

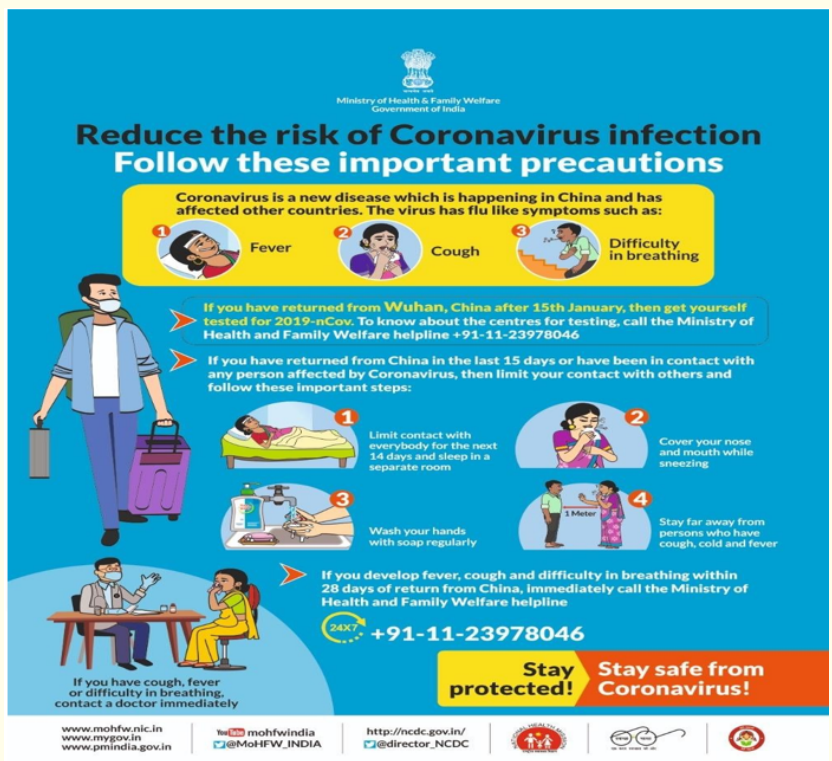

Figure 5

Form A

NATIONAL CENTRE FOR DISEASE CONTROL

(To be filled for 2019-nCoV Acute Respiratory Disease)

\begin{tabular}{|c|c|c|c|c|c|}
\hline \multirow[t]{2}{*}{ A } & \multicolumn{5}{|l|}{ PATIENT INFORMATION } \\
\hline & Date of reporting to health facility: & \multicolumn{3}{|c|}{$\begin{array}{l}\text { Name of Reporting Health Facil- } \\
\text { ity: }\end{array}$} & Date of interview \\
\hline & \multicolumn{2}{|l|}{ State } & \multicolumn{3}{|c|}{ Local Patient ID......................... } \\
\hline & Name of interviewer & \multirow[t]{2}{*}{$\begin{array}{l}\text { Address of } \\
\text { interviewer: }\end{array}$} & \multicolumn{3}{|c|}{ Contact Number of interviewer } \\
\hline & Name of patient: & & \multicolumn{2}{|l|}{ Age } & Gender \\
\hline & \multicolumn{4}{|l|}{ Case Classification*: Confirmed } & \\
\hline \multirow[t]{3}{*}{ B } & \multicolumn{5}{|l|}{ SOCIODEMOGRAPHC PROFILE } \\
\hline & \multicolumn{5}{|c|}{ 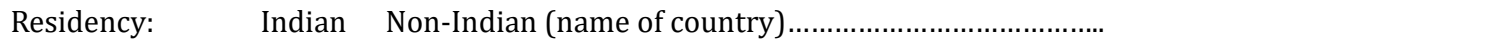 } \\
\hline & Postal Address & District & $\begin{array}{l}\mathrm{P} \text { h o n e } \\
\text { number }\end{array}$ & email i & \\
\hline C & \multicolumn{5}{|l|}{ CLINICAL INFORMATION } \\
\hline 1 & \multicolumn{5}{|l|}{ Patient clinical course } \\
\hline 1.1 & \multicolumn{5}{|l|}{ Date of Onset of symptoms } \\
\hline 1.2 & \multicolumn{4}{|l|}{ Date of first contact with heath facility } & ) \\
\hline 1.3 & \multicolumn{4}{|c|}{ (name of health facility: } & ) \\
\hline 1.4 & \multicolumn{2}{|c|}{ Outcome (circle): Under treatment/ Discharged/ LAMA/ Died/ Cured } & \multicolumn{3}{|c|}{ 1.5Date of death (if applicable) } \\
\hline 1.6 & \multicolumn{2}{|c|}{ Cause of death (As mentioned on death certificate): } & & & \\
\hline 1.7 & \multicolumn{5}{|l|}{ Was patient ventilated Yes/No } \\
\hline
\end{tabular}




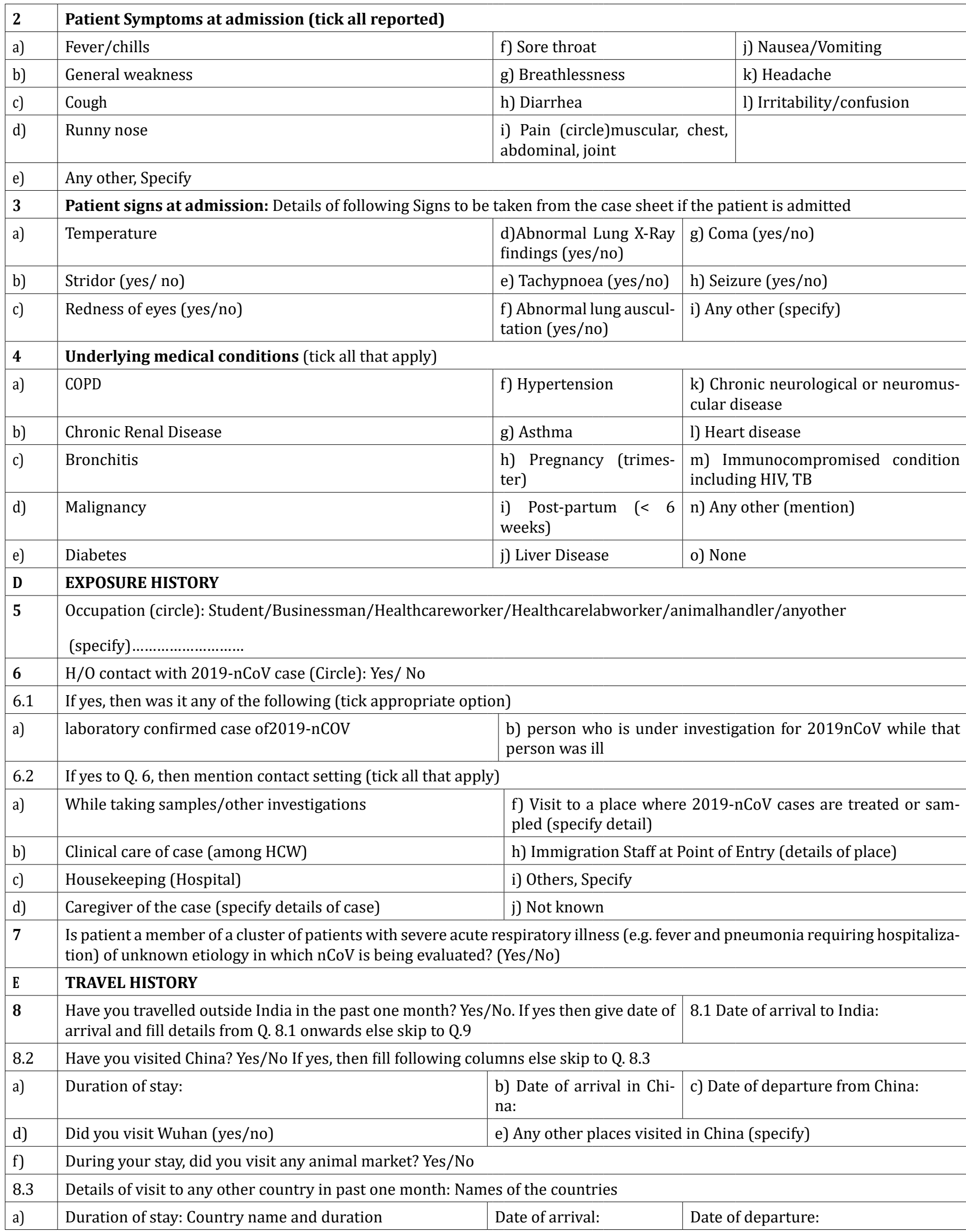




\begin{tabular}{|l|l|l|l|}
\hline b) & Duration of stay: Country name and duration & Date of arrival: & Date of departure: \\
\hline $\mathbf{9}$ & Have you travelled within India in the past one month? Yes/ No. If no, skip to Section F \\
\hline & If yes, details of visit to other places: Names of places & \multicolumn{2}{|l|}{} \\
\hline a) & Duration of stay: Place and duration & Date of arrival: & Date of departure: \\
\hline b) & Duration of stay: Place and duration & Date of arrival: & Date of departure: \\
\hline c) & Duration of stay: Place and duration & \\
\hline F & LABORATORY INFORMATION (to be obtained from treating physician) & \\
\hline 10 & Any sample collected for confirmation of 2019-nCoV case (y/n) & Result \\
\hline a) & If yes, then Type of sample collected Date of collection Sentto Test Performed $\quad$ Result \\
\hline b) & If yes, then Type of sample collected Date of collection Sentto Test Performed $\quad$ Result \\
\hline c) & If yes, then Type of sample collected Date of collection Sentto Test Performed $\quad$ Result \\
\hline
\end{tabular}

Table 5

\section{Discharge policy of $\mathrm{nCoV}-19$ case}

Clinical samples of any suspect/probable case of nCoV will be sent for laboratory confirmation to designated laboratories. The case will be kept in isolation at health facility till the time of receipt of laboratory results and given symptomatic treatment as per existing guidelines. If the laboratory results for $\mathrm{nCoV}$ are negative, the discharge of such patients will be governed by his provisional/ confirmed diagnosis and it is up to the treating physician to take a decision. The case shall still be monitored for 14days after their last contact with a confirmed 2019-nCoV case. In case the laboratory results are positive for $\mathrm{nCoV}$, the case shall be managed as per the confirmed case management protocol. The case shall be discharged only after evidence of chest radiographic clearance and viral clearance in respiratory samples after two specimens test negative for $\mathrm{nCoV}$ within a period of 24 hours.

- The ambulance staff should follow standard precautions while handling the patient and airborne precautions if aerosol generating procedures are done.

- Triple layer surgical masks should be available and worn during transport.

- As far as possible the movements should be restricted.

- During transport, optimize the vehicle's ventilation to increase the volume of air exchange (e.g. opening the windows). When possible, use vehicles that have separate driver and patient compartments.

- Aerosol generating procedures to be avoided to the extent possible.

- Disinfect the ambulance after shifting patient with Mifog (1\%)

- Notify the receiving facility as soon as possible.

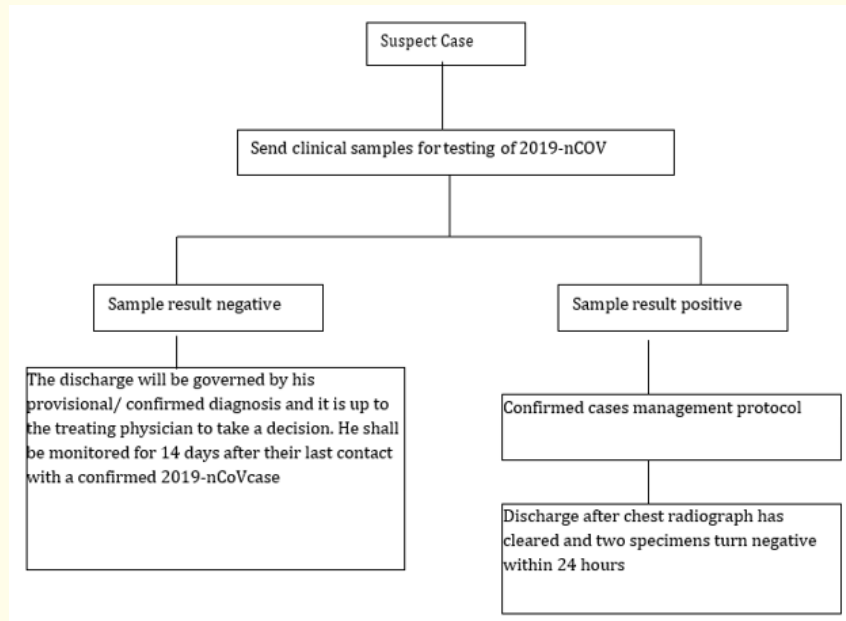

Figure 6

Guidelines for setting up screening centre purpose of the screening centre is to:

- $\quad$ Attend to patients of $2019 \mathrm{nCoV}$-Acute Respiratory Disease in a separate area so as to avoid these patients further infecting other patients in Out Patient Department.

- Facilitate implementing standard and droplet precautions.

- $\quad$ Triage the patients.

- $\quad$ Collect samples.

The screening area should have:

- A waiting area of about 2000 sq feet to accommodate 50 - 100 patients.

- Preferably standalone building with separate entry.

- Well ventilated to ensure frequent air changes. If air condi- 
tioned, then independent from central air conditioning. Exhaust air to be filtered through HEPA filter (desirable).

- $\quad$ Patient's seating to have at least one meter clearance on all sides.

- Avoid overcrowding of patients.

- Will have cabins for registration, clinical examination chambers, sample collection rooms and drug distribution centre.

- The waiting area should be adequately cleaned and disinfected.

- $\quad$ Source control (e.g. use of tissues, handkerchiefs, piece of cloth or triple layer surgical masks to cover nose and mouth) of the patient in the waiting room when coughing or sneezing, and hand hygiene after contact with respiratory secretions.

- $\quad$ Facility for hand washes/Wash rooms etc.

Guidelines for setting up isolation facility/ward

- $\quad$ Patients should be housed in single rooms, whenever possible.

- However, if sufficient single rooms are not available, beds could be put with a spatial separation of at least 1 meter $(3$ feet) from one another.

- To create a 10 bed facility, a minimum space of 2000 square feet area clearly segregated from other patient care areas is required.

- There should be double door entry with changing room and nursing station. Enough PPE should be available in the changing room with waste disposal bins to collect used PPEs.

- $\quad$ Place a puncture-proof container for sharps disposal inside the isolation room/area.

- $\quad$ Keep the patient's personal belongings to a minimum. Keep water pitchers and cups, tissue wipes, and all items necessary for attending to personal hygiene within the patient's reach.

- Non-critical patient-care equipment (e.g. stethoscope, thermometer, blood pressure cuff, and sphygmomanometer) should be dedicated to the patient, if possible. Any patientcare equipment that is required for use by other patients should be thoroughly cleaned and disinfected before use.

- Dedicated hand washing and wash room facilities.

- If room is air-conditioned, ensure 12 air changes/hour and filtering of exhaust air. A negative pressure in isolation rooms is desirable for patients requiring aerosolization procedures (intubation, suction nebulization). These rooms may have standalone air-conditioning. These areas should not be a part of the central air-conditioning.
- If air-conditioning is not available negative pressure could also be created through putting up 3 - 4 exhaust fans driving air out of the room.

- In district hospital, where there is sufficient space, natural ventilation may be followed. Such isolation facility should have large windows on opposite walls of the room allowing a natural unidirectional flow and air changes. The principle of natural ventilation is to allow and enhance the flow of outdoor air by natural forces such as wind and thermal buoyancy forces from one opening to another to achieve the desirable air change per hour.

- Avoid sharing of equipment, but if unavoidable, ensure that reusable equipment is appropriately disinfected between patients.

- Ensure regular cleaning and proper disinfection of common areas, and adequate hand hygiene by patients, visitors and caregivers.

- Visitors to the isolation facility should be restricted. For unavoidable entries, they should use PPE according to the hospital guidance, and should be instructed on its proper use and in hand hygiene practices prior to entry into the isolation room/ area.

- Doctors, nurses and paramedics posted to isolation facility need to be dedicated and not allowed to work in other patientcare areas.

- Consider having designated portable X-ray equipment.

- Corridors with frequent patient transport should be well-ventilated.

- $\quad$ All health staff involved in patient care should be well trained in the use of PPE.

- A telephone or other method of communication should be set up in the isolation room/area to enable patients or family members/visitors to communicate with nurses.

Guidelines for critical care facility

- At least one identified hospital may have a 10 bed dedicated intensive care facility at state capital.

- The critical care facility is required to follow all the guidelines as mentioned above for infection control.

- Also more than or equal to 12 air changes and maintain negative pressure of 40 psi.

- Should have dedicated equipment's. It should also have additional equipment to ventilate at least 10 patients manually. 
- A telephone or other method of communication should be setup in the isolation room/area to enable patients or family members/visitors to communicate with nurses inside the facility.

- Would have an information board outside to update relatives on the clinical status.

\section{Mortuary care}

- Mortuary staff should apply standard precautions i.e. perform proper hand hygiene and use appropriate PPE (use of gown, gloves, facial protection if there is a risk of splashes from patient's body fluids/secretions onto staff's body and face).

- Embalming, if required should be conducted according to usual procedures, subject to local regulations/legislation.

- Hygienic preparation of the deceased (e.g. cleaning of body, tidying of hair etc.) also may be done using standard precautions [3-5].

Quarantine for healthcare workers

\begin{tabular}{|c|c|c|c|}
\hline $\begin{array}{l}\text { Epidemiologic } \\
\text { risk factors }\end{array}$ & $\begin{array}{l}\text { Exposure } \\
\text { category }\end{array}$ & $\begin{array}{l}\text { Recommended } \\
\text { Monitoring for } \\
\text { COVID-19 (until } \\
14 \text { days after } \\
\text { last potential } \\
\text { exposure) }\end{array}$ & $\begin{array}{l}\text { Work Re- } \\
\text { strictions } \\
\text { for Asymp- } \\
\text { tomatic } \\
\text { HCP }\end{array}$ \\
\hline \multicolumn{4}{|c|}{$\begin{array}{c}\text { Prolonged close contact with a COVID-19 patient who was } \\
\text { wearing a facemask (i.e., source control) }\end{array}$} \\
\hline HCP PPE: None & Medium & Active & $\begin{array}{l}\text { Exclude } \\
\text { from work } \\
\text { for } 14 \text { days } \\
\text { after last } \\
\text { exposure }\end{array}$ \\
\hline $\begin{array}{l}\text { HCP PPE: Not } \\
\text { wearing a face- } \\
\text { mask or respira- } \\
\text { tor }\end{array}$ & Medium & Active & $\begin{array}{l}\text { Exclude } \\
\text { from work } \\
\text { for } 14 \text { days } \\
\text { after last } \\
\text { exposure }\end{array}$ \\
\hline $\begin{array}{l}\text { HCP PPE: Not } \\
\text { wearing eye pro- } \\
\text { tection }\end{array}$ & Low & $\begin{array}{l}\text { Self with delegat- } \\
\text { ed supervision }\end{array}$ & None \\
\hline $\begin{array}{l}\text { HCP PPE: Not } \\
\text { wearing gown or } \\
\text { gloves }^{\text {a }}\end{array}$ & Low & $\begin{array}{l}\text { Self with delegat- } \\
\text { ed supervision }\end{array}$ & None \\
\hline $\begin{array}{l}\text { HCP PPE: Wear- } \\
\text { ing all recom- } \\
\text { mended PPE } \\
\text { (except wearing a } \\
\text { facemask instead } \\
\text { of a respirator) }\end{array}$ & Low & $\begin{array}{l}\text { Self with delegat- } \\
\text { ed supervision }\end{array}$ & None \\
\hline \multicolumn{4}{|c|}{$\begin{array}{l}\text { Prolonged close contact with a COVID-19 patient who was } \\
\text { not wearing a facemask (i.e., no source control) }\end{array}$} \\
\hline
\end{tabular}

\begin{tabular}{|c|c|c|c|}
\hline HCP PPE: None & High & Active & $\begin{array}{l}\text { Exclude } \\
\text { from work } \\
\text { for } 14 \text { days } \\
\text { after last } \\
\text { exposure }\end{array}$ \\
\hline $\begin{array}{l}\text { HCP PPE: Not } \\
\text { wearing a } \\
\text { facemask or } \\
\text { respirator }\end{array}$ & High & Active & $\begin{array}{l}\text { Exclude } \\
\text { from work } \\
\text { for } 14 \text { days } \\
\text { after last } \\
\text { exposure }\end{array}$ \\
\hline $\begin{array}{l}\text { HCP PPE: Not } \\
\text { wearing eye } \\
\text { protection }^{b}\end{array}$ & Medium & Active & $\begin{array}{l}\text { Exclude } \\
\text { from work } \\
\text { for } 14 \text { days } \\
\text { after last } \\
\text { exposure }\end{array}$ \\
\hline $\begin{array}{l}\text { HCP PPE: Not } \\
\text { wearing gown or } \\
\text { gloves }^{\mathrm{a}, \mathrm{b}}\end{array}$ & Low & $\begin{array}{l}\text { Self with delegat- } \\
\text { ed supervision }\end{array}$ & None \\
\hline $\begin{array}{l}\text { HCP PPE: Wear- } \\
\text { ing all recom- } \\
\text { mended PPE } \\
\text { (except wearing a } \\
\text { facemask instead } \\
\text { of a respirator) }^{\mathrm{b}}\end{array}$ & Low & $\begin{array}{l}\text { Self with delegat- } \\
\text { ed supervision }\end{array}$ & None \\
\hline
\end{tabular}

Table 6

\section{Conclusion}

The recent emergence of covid-19 means that understanding of transmission patterns, clinical features and risk factors for infection remains limited whether about the general population and health workers.

Hospital-related infections have been widely reported during the ongoing coronavirus outbreak, with healthcare professionals bearing a disproportionate risk. However, the main perspective is to have bucked this trend and successfully protect both patients and staff from SARS-CoV-2.

The motive of this research is to create a standard protocol so as to prevent our hospital staff from infection.

\section{Bibliography}

1. National guidelines for infection prevention and control in healthcare facilities.

2. Guidelines on Clinical Management of COVID-19.

3. World Health Organization. "Coronavirus disease 2019 (COVID-19) situation report-45" (2020).

4. Donnelly CA., et al. "Epidemiological determinants of spread of causal agent of severe acute respiratory syndrome in Hong Kong". Lancet 361.9371 (2003): 1761-1766. 
5. World Health Organization. Coronavirus disease 2019 (COVID-19) situation report-32, 21 Feb 2020 National Institute of Infectious Diseases. Japan. Field briefing: Diamond Princess COVID-19 cases (2020).

\section{Assets from publication with us}

- Prompt Acknowledgement after receiving the article

- Thorough Double blinded peer review

- Rapid Publication

- Issue of Publication Certificate

- High visibility of your Published work

Website: https://www.actascientific.com/

Submit Article: https://www.actascientific.com/submission.php Email us: editor@actascientific.com

Contact us: +919182824667 